\title{
Confusão das confusões: precisa-se que a argumentação seja lógica
}

Isabel Santos ${ }^{1}$

Une tête bien faite vaut mieux qu'une tête bien pleine. Michel de Montaigne

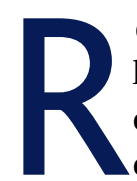
ecentemente o Sr. Ministro da Ciência, Tecnologia e Ensino Superior, numa entrevista ${ }^{1}$ a um órgão de comunicação, fez declarações que conduziram a múltiplas interrogações e declarações institucionais condenatórias. ${ }^{2}$

Essa entrevista, para além de revelar ignorância sobre a Medicina Geral e Familiar, sobre o que se faz nesta especialidade, revela erros comuns de raciocínio e lógica discursiva. Se as premissas ou os axiomas são falsos, nem a argumentação nem as conclusões são válidas.

Médicos de Família são médicos especialistas em Medicina Geral e Familiar, com um internato médico de quatro anos de formação, durante o qual adquirem e treinam um conjunto alargado de competências que definem o perfil de intervenção a que serão chamados diariamente no exercício médico. Os licenciados ou mestres em medicina podem exercer medicina em diversos contextos, seja nos cuidados de saúde primários seja no hospital, mas não serão cirurgiões por estarem na pequena cirurgia da urgência ou internistas por servirem sob a sua responsabilidade, nem para a sociedade nem para o Sr. Ministro, que naturalmente quererá ser tratado por um Especialista. A analogia feita, que estabelece como sendo idênticas duas situações diversas, licenciado ou Mestre em Medicina e Especialista, tratando ambas como uma situação em si, está errada.

As analogias são muito importantes para a lógica e para o pensamento abstrato, mas quando se estabelece uma analogia entre A e B é preciso clarificar qual é o

1. Professora reformada. NOVA Medical School, Faculdade de Ciências Médicas. Lisboa, Portugal. princípio abstracto implícito que torna análogos o conceito A e o conceito B. O Sr. Ministro faz equivaler o argumento de falta de médicos, que não explicita nem prova, ao argumento do exagero de exigência formativa de um médico de família. Isto é uma falsa equivalência. Fazer equivaler erradamente um argumento a outro é uma tática enganadora e não é lógica.

O perfil de um especialista de Medicina Geral e Familiar é complexo e o Sr. Ministro, como muitas outras pessoas, não o conhece, fazendo o erro comum de reduzir o todo a uma parte, pensando que um conjunto de partes, ainda que muito limitadas, faz o todo. Ora, o que caracteriza um especialista não é somente o conteúdo da sua arte, as partes em que esta se decompõe, a sua capacidade em separar, diferenciar, selecionar e excluir, mas a capacidade de religar, de colocar um conhecimento particular no seu contexto e situá-lo num conjunto. ${ }^{3} \mathrm{O}$ especialista em Medicina Geral e Familiar é o médico que lida com o maior e mais abrangente leque de problemas de saúde e de tomadas de decisão em pessoas, com idades e origens muito diversas. Isso requer religar muitos conhecimentos e reconhecer a unidade no seio do diverso e o diverso no seio da unidade. Requer tempo de formação.

A especialidade de Medicina Geral e Familiar é global, não é uma simples soma de competências. Um licenciado médico, mesmo capaz de assegurar um conjunto de tarefas que se enquadram no perfil de uma especialidade, não se pode intitular especialista. Ao fazê-lo, o Sr. Ministro quer reduzir o complexo ao simples. Claudica ao não propor corretivos para a ignorância e para a cegueira do inconveniente da sobre-especialização, da compartimentação e do parcelamento do saber, e simplifica, decompondo e eliminando tudo o que traz desordem ou contradição ao seu pensamento preformado. 
O Sr. Ministro considera existir falta de diversidade na formação médica e esta sua convicção leva-o a declarar ser provável poder formar médicos de família em menos tempo. Esta relação não é compreensível. A que se refere quando diz haver falta de diversidade? A diversidade é um objetivo em si mesmo? O antónimo de diversidade é homogeneidade. Ora esta não deve ser confundida com uniformidade. A homogeneidade supõe objetivos comuns para os quais podemos todos convergir através de itinerários originais, quando a uniformidade impõe os mesmos percursos para atingir os mesmos objetivos. O ensino pré-graduado da medicina deve ser homogéneo no perfil de competências do jovem médico pluripotencial, mas deve evitar a uniformidade, permitindo personalizar os percursos para alcançar os objetivos.

Assim como no mar há diferentes categorias de cartas para navegar, principiante, marinheiro, patrão de costa e patrão de alto mar, também no exercício responsável da Medicina existem diferentes tipos de certificação. O Sr. Ministro da Ciência devia saber isso. Mas nós também o devemos saber.

Na realidade, no nosso ensino pré e pós-graduado é escassa, ou ausente, a formação curricular em Lógica ou sobre Pensamento Crítico e pouca atenção é dada à avaliação crítica de diferentes teses. Contestam-se as conclusões, mas não se desconstrói o pensamento que as originou.

Para fazer aceitar a verdade de diferentes declarações oferece-se frequentemente, como evidência, presunções e não razões e estabelecem-se ligações de causalidade usando um modelo explicativo de causalidade biunívoco. É este tipo de raciocínio que aparece na entrevista do Sr. Ministro, que salta de uma afirmação ambígua para uma outra, deixando demasiados passos pelo meio por esclarecer e chega a conclusões sem verdadeiro uso da lógica. ${ }^{4}$

Este tipo de argumentação é frequentemente usado na prática política, mas também invade as nossas discussões sobre a organização dos serviços, a análise de sistemas de saúde e a estrutura da formação, em particular no internato médico, sendo que estas discussões são frequentemente secundadas por berros e insultos.

Como no raciocínio do Sr. Ministro, também nós pensamos muitas vezes que basta saber para fazer e que um algoritmo de decisão pode fazer um médico de família, sobretudo na altura em que se aproxima o exame final dos internatos de especialidade. A prática comporta uma dimensão formativa, mas para que a experiência se torne um momento de formação (estágio) é necessário satisfazer duas exigências em simultâneo, uma qualitativa e outra quantitativa: uma exigência quantitativa, porque é necessário calcular a carga de trabalho que deve ser considerada suficiente para permitir uma abordagem realista à profissão; e uma exigência qualitativa, pois é necessário que o ambiente proporcione a dinamização da experiência para que exista uma relação transformadora da prática. O modelo de formação profissional do Sr. Ministro parece ser o de modelização exclusiva see one, do one, incompatível com a formação profissional de um médico especialista.

Não se pretendem analisar aqui todas as premissas que sustentam o raciocínio condicional, o erro das inferências ou o modus tollens do Sr. Ministro. O que desejamos realçar é que sempre que se faz uma afirmação é preciso andar para trás e perguntar porquê, questionar as premissas, os alicerces do pensamento e os modelos teóricos que os sustentam. Nas ciências sociais, a explicação causal traduz-se no enunciado de uma pluralidade de condições determinantes cuja verificação simultânea confere um certo grau de probabilidade à ocorrência de determinados resultados. ${ }^{5} \mathrm{En}$ tender como causa um acontecimento singular é comum na população geral, mas não pode ser no Sr. Ministro nem nos profissionais de saúde. Tendo uma formação de nível superior, somos responsáveis por uma exigência e um rigor também superiores.

A ciência é uma construção social, que resulta não apenas de processos de investigação, mas também do discurso e do escrutínio público usados para resolver controvérsias e chegar a um consenso. Fazer da argumentação lógica e do pensamento crítico componentes-chave do ensino e da formação em geral e em medicina, seja qual for o grau de diferenciação, é um imperativo. ${ }^{6}$

\section{REFERÊNCIAS BIBLIOGRÁFICAS}

1. Meireles A.A partir de outubro, a oferta de ensino superior será em 134 localidades. Diário de Noticias. 2021 Sep 2 [cited 2021 Oct 5]. Available from: https://www.dn.pt/sociedade/a-partir-de-outubro-a-ofertade-ensino-superior-sera-em-134-localidades-14080918.html

2. Ordem dos Médicos. Declaração do Fórum Médico sobre a entrevista 
do Ministro da Ciência, Tecnologia e Ensino Superior. Ordem dos Médicos; 2021 Sep 4 [cited 2021 Sep 26]. Available from: https://ordemdosmedicos.pt/declaracao-do-forum-medico0309/

3. Morin E. Repensar a reforma, reformar o pensamento: a cabeça bem feita. Lisboa: Instituto Piaget; 1999. ISBN 9789727715411

4. Cheng E. A arte da lógica num mundo ilógico. Lisboa: Temas e Debates; 2020. ISBN 9789896445577

5. Almeida JF, Pinto JM, Cruzeiro ME. A propósito do problema da causa- lidade em ciências sociais: o modelo de decomposição de proporções de R. Boudon. Anal Social. 1973;X(40):734-77.

6. Thomson A. Critical reasoning: a practical introduction. London: Routledge; 1996.

\section{ENDEREÇO PARA CORRESPONDÊNCIA}

E-mail: misabelpsantos@gmail.com

https://orcid.org/0000-0001-9320-6451 